\title{
RECOLLECTIONS OF A PIONEER TEACHER OF HAMILTON COUNTY
}

\section{By Agnes Briggs Olmstead}

The stranger at my fireside cannot see the forms I see, Nor hear the sounds I hear;

He but perceives what is, while to me all that has been Is visible and clear.

-Longfellow.

When my ever staunch friend, editor Charles Aldrich, 1 urged me to write for the ANNALs something of the recollections of a pioneer schoolteacher, he evidently considered my experiences more varied and full of incident than they really were. Being only a country schoolma'am, to strangers, such a restrospection must necessarily be commonplace; while to me, these memories are so large a part of heart and life, that aside from them there is scarce anything left.

Hamilton county, in which most of my teaching was done, had almost passed the pioneer stage and the much vaunted days of log schoolhouses with puncheon floors and shake roofs were over long before I entered the lists as a teacher. True, when first we came to this county in 1858, I did attend school in such a structure. The following summer it was removed, and just such a neat, white, frame building took its place as now dots the center of nearly every school-district in Iowa.

1These recollections were written in 1902 or 1903 for THE ANNALs of IowA, at the request of the late Charles Aldrich, then editor, by Agnes Briggs, a pioneer at the request of the late Charles Al, Iowa. The original manuscript was revised school teacher of Hamilton county, lowa. The original manuscript was revised the daughter of Ulysses and Ellen Briggs and was born near Pittsburg, Penn., the daughter of 12,1848 . She came west with her parents to Jackson and Dubuque counties, Aug. 12, 1848. She came west with her parents county in 1856. About 1866 the family removed to Boone township where the permanent Briggs home was built in what is now known as Briggs Woods.

She was the second child in a family of eight children and herself attended a pioneer country school in Cass township but began her teaching career in Boone pioneer coun 1867 at the age of nireteen. This continued to be her profession until her marriage to a young attorney, George C. Olmstead, on October 22, 1885. Her death occurred at the Briggs farm home on October 17, 1911 at the age of sixty-three years.

As a teacher she was ever respected and admired by her pupils, who still think of her as an outstanding influence in their youth. She was widely known think of her as an outstan speaker and writer, who was particularly well versed in the classics. Her private library was considered one of the finest collections of choice volumes to be found in this section of the state. 
But even this uncouth log schoolhouse has its memory, for here was held the only Sabbath service in Cass township, and hither once in two weeks, came a young minister, the Rev. O. A. Holmes ${ }^{2}$ of Webster City, to break the bread of life to a little handful of pioneers.

The first time I saw him in the pulpit (?) he wore a large check, black and white coat that made him much resemble an animated checkerboard, and he was barefoot. I failed to understand the fineness of the action then; had I been older, I should have recognized a hero fitted to become what he afterwards was-one of the best beloved and prominent ministers of the Baptist church in Iowa.

It was a lovely morning in early May, 1867, when, leaving my woodland home on the banks of the Boone, I set out on the long walk that was the beginning of a new era in my life. Hitherto I had been as a child to be taught and led; now I was to assume the responsibility of teacher and guide to others. I had no forebodings of failure nor bright visions of success. I simply planned to do with my whole might the duty that lay nearest my hand. Before me lay a broad stretch of undulating prairie, seared and blackened by the fires that had swept over it. I might almost speak of it as a trackless waste, as for the greater part of the way, there was no wagon track nor even a footpath until one was worn by my own feet.

At this time there was not one enclosed farm on the south side of my road, though there were two on the north. Seven prairie creeks intersected my path and as

Rev. O. A. Holmes was one of the leading and most successful Baptist preachers of the state in the early days. He organized dozens of churches in Iowa and other western states. Among these were the churches at Webster City, Iowa Falls, Fort Dodge and Boone. He was pastor of the Webster City church
from 1858 to 1867 .

sThe Hunt school was located out on the prairies about five miles east and a little south of the Briggs home. The remains of the foundation of the home of John Hunt, the school director, may still be seen across the road north from the farm home of John $\mathbf{H}$. Tapper who lives north and east of Kamrar. Across the fields north and west about a half mile is the site of the so-called Hunt school.

John Hunt came to this county in 1864 with his wife and three daughtera, Hulda, Jessie, and Doretha. Hulda died in early youth, Jessie in 1910, Doretha
in 1936 after many years of service as recorder of Hamilton county. 
many times were my "hosen and shoon" removed to wade across them. They were usually from one to two feet in depth, and if I remember rightly, there was no time during that summer when any of them were low enough to cross dry-shod. Once or twice however after heavy rains I have unexpectedly plunged in chin-deep. There was no current, however, so $I$ was in no danger of drowning.

I was to teach what was known as the Hunt school, ${ }^{3}$ five miles east from my home, and here I arrived about half past eight, thoroughly tired out with my toilsome walk. The school house was one of the neatest, littlest structures in which I have ever been privileged to teach - "perfect and entire and clean" inside and out. Three pupils, daughters of the school director, awaited me. They proved to be the most docile and willing of pupils, and during the two years that I remained there, I cannot recall that they ever gave me a moment's pain or annoyance.

The settlement appeared to consist of two families. At least, there were just two dwellings that I could see as I took a survey of my surroundings. At one of these places I was to board and about six o'clock I slowly wended my way in that direction.

The house was a low, weather-beaten structure consisting of a front-room and a back-kitchen. Each of the two rooms was occupied by a separate family. I boarded with the front-room family which comprised an old man and his wife, a small son and a hired girl. I was to stay with them four days out of each week and pay them three dollars, with twenty-five cents less if I drank neither tea nor coffee. As this was but a little more than half of my salary, I considered the price reasonable and so the bargain was settled. Our bill of fare, embracing just five articles, was made out according to the laws of the Medes and Persians, which altereth not.

I did not object to this but there were "some of the customs o' the family" that I did object to most decidedly 
and after sixteen days of trying to adjust myself to the living conditions of this household, I finally came to myself and said: "I will arise and go to my father's house." And so, for the remainder of the time I walked the five miles back and forth between my home and the school daily.

I was often very, very tired and at times my feet almost refused to bear me further and wading creeks grew monotonous. In the moist places the grass grew so tall that the bending tops met over my head, shutting out the sunlight. The hard rough leaves at the base of the stems would cut into my bare limbs, until I could not place a finger-tip from knee to toe, where the blood had not started. I used to feel sorry for myself' as I watched the crimson drops slowly trickling down and perhaps cry a little. ${ }^{4}$

And yet I woud rather have paid the price it cost me than be deprived of the memory of those long walks. The real delight and satisfaction in them will be to me a joy forever.

\section{COMPANIONSHIP WITH NATURE}

Not the least of my pleasure was the sense of boundless freedom, of being no longer shut in. Here was elbow room, breathing space; above, the vast blue canopy of heaven; beneath, a deep gulf of billow verdure, and the great glad sun pouring its radiance over all and everything so clean, so pure, so fresh.

'Many a time, as a I walked in the early morning, I watched the darkness dissolve into dawn while the stars, like weary watchers, drowsily closed their eyes. I have seen the sun rise from a cloudy bed of amethyst and gold; noted the changing landscape as it was gradually revealed in the growing light. Many a glorious sunset have I seen and how often caught the first shy glance of the evening-star. I have traced many a meteor along its fiery pathway, until it seemed to fall to earth shattered

4Among the tall grasses mentioned was the prairie blue stem, which grew to a great height on the open prairie and had a coarse rough stalk. 
into a thousand burning fragments. I have even seen the Aurora Borealis drape the whole sky from zenith to horizon, with fold on fold of soft, shimmering curtains of rose and gold.

I kept a calendar for bud and flower and leaf, until they seemed to come and go as I announced the days. Morning after morning, ever with the same delight, I have listened to the matins of the meadow-lark as he celebrated earth's glory. In the evening I have waited to hear the bobolink chant his vespers and then when all the birds together sang their song of jubilee, I was present.

But birds were not my only companions. Occasionally I would see a fox trotting along. . Sometimes a solitary wolf would suddenly emerge from the tall grass near my path and, after eyeing me for a moment, beat a hasty retreat with a look of intense disgust on his face. In the early winter, when more than half of my daily journey was made in the dark, I could hear the wolves barking raggedly and howling like demons as they ranged the desolate prairies, as if pandemonium were let loose.

Snakes were most abundant, principally the harmless varieties. Hurrying along one evening, I suddenly came upon the enormous body of one lying squarely across my path. Though I passed cautiously along until about five feet of his snakeship had passed under review, he never moved. As I had not the faintest idea where either extremity might be located, I made a circuit of a quarter of a mile in order to avoid disturbing him.

Another time I came a little nearer meeting with a dangerous adventure. It was on the evening of an intensely warm day in July. I had walked about two miles, was hungry, thirsty, and numb with weariness. Hardly conscious of what I was doing, I dropped down by the roadside to rest a minute. In a moment my head had dropped forward and I was asleep. I must have slept an hour when I awoke with a start. Quickly gathering myself together, I started to descend the little 
slope bordering a creek, when I noticed a swaying of the tall grass on my right. "There's a snake there if I am not mistaken," I thought, "and from the motion of the grass, he must be immense, and well worth seeing. I think I'll find out." Cautiously I pushed aside the grass, and there facing me, with very few feet of space between us, was the handsomest reptile I have ever seen-a lovely azure blue, with large calm eyes of black and gold that betrayed neither alarm nor hostility as they met mine. Some three feet of his graceful length emerged from the dense growth and lay half reclining on the recumbent stalks of grass. His head was raised about two feet from the ground. He was so perfectly beautiful I could not take my eyes away. Suddenly he made a spring. The shock was terrible, but, quick as he was, I was quicker and with one great leap I cleared the slope and fairly flew over the next half mile. I had heard of blue racers before but had never seen one. And I had no mind to try the tender embraces of this one.

The oddest part of the adventure was yet to come. Twilight was deepening into dusk and I was nearing home when my sister, Thirza, unexpectedly appeared in my path. " $O$," she cried, "what has been the matter with you? What trouble have you met with?"

"None at all," I replied, "I've had no trouble."

"Then why did you call?" she asked.

"I didn't call, and everything has been remarkably still. I've scarcely heard a sound but the chirp of a grasshopper."

"But you did call. We all heard you. Three times the call came, distinct and clear. It was your voice and you spoke my name as no one outside the family ever speaks it." We never knew who called that night, but I have a vague impression that my curiosity came near costing me dear-but that snake was a handsome fellow. ${ }^{5}$

\footnotetext{
5Frank Briggs, a brother of Agnes and at this time a small boy of five years, remembers this incident well. He recalls that the cry of his sister was distinctly heard by several members of the family.
} 
Another evening I came across an enormous geometric spider. I never saw a finer specimen. The body as nearly as I could measure it with my eye, was two and a half inches in length, while the legs had a span of eight inches or more. The cephalo-thorax was a vivid yellow, bright as the petal of a buttercup; the abdomen was striped with alternate velvety bands of jet black and snow white. She was balanced in the center of a magnificent web some four feet square attached to two tall stalks of compass plant or gum weed. As I stood watching, a heedless katydid landed in the lower edge of the snare. Like a flash the spider swooped down upon her helpless victim, and in a moment it was so firmly bound, wing and foot, that further struggle was impossible. When I returned on Monday morning both queen spider and palace had alike disappeared.

\section{Firm Friendships Established}

But all the time I was growing familiar with these wild creatures, I was making human acquaintances as well. Among the earliest and truest of these were the members of the Hunt family. As Mr. Hunt was the director and for a time, the daughters, my only pupils, I was soon on friendly footing with them all. Thus early began a friendship, which, for thirty years, has continued without change. They were unique. Each was a strong and decided character, reminding me in many ways of the old New England Puritans. Husband and wife were one in struggle and aspiration, one in sympathy and burden bearing, and the daughters accorded them a trustful and loyal devotion, beautiful to see.

If ever a man was fashioned to pioneer a forlorn hope, or live wholly within his own resources, that was John Hunt. Firm of purpose, energetic and persevering and possessed of remarkable mechanical ingenuity, he was a whole colony of mechanics and trades people within himself. Few indeed were the needs of the average pioneer family which his industry and skill could not supply. ${ }^{3}$ 
Their own farm produced the flax which, woven in their own loom, furnished table linen, bedding, towelling, and underwear. Wool used for winter clothing was raised, spun and woven in the home. If shoes were needed, Mr. Hunt would don his leather apron and shape a shoe but little inferior in appearance to a factory made article and far superior in durability.

A small blacksmith shop stood near the house where he repaired machinery and shod horses. He was an excellent carpenter, and no man could do better cabinet work. In short, if there was any branch of mechanical labor in which he did not excel, I failed to discover it; while Mrs. Hunt was as skillful and thorough in her departments as he was in his.

Huldah, the eldest daughter, was a most exemplary girl; the pride and comfort of her father, the stay and support of her mother, the guide of her younger sisters, a faithful friend and a model pupil. At the end of my two years of work here she took charge of the school, when I accepted a position a little nearer home. For two years she did the work of a faithful teacher. Then, just four years from the day on which we first entered upon the mutual relations of teacher and pupil-"God's hand beckoned unawares, And the sweet, white brow was all of her."

Happily the family circle was not again broken in upon by death until twenty years later, when the father was called. Jessie, the second daughter, prepared herself for a teacher, but precarious health compelled her to resign this work. Doretha, the youngest, has for many years been one of Hamilton county's most successful and efficient teachers. The little mother, now in her eightythird year, is calmly waiting a joyful reunion with the husband of her youth.

Immediately after the close of the fall term in the Hunt district, I began teaching the winter term of the home 
school, now known as the Woodleaf school. ${ }^{6}$ I remember this as a particularly disagreeable winter. The weather was severe, the schoolhouse indescribably forlorn and dilapidated. The desks were in all stages of demoralization. The dictionary had been used for a billiard ball until it was a handful of shreds and patches. The few scattered bits of plaster, which still adherred to the wall, furnished small protection from the keen northwest winds that played hide and seek through a thousand crevices. The snow drifted in through the roof. The outside walls were guiltless of paint. Here and there one wing of a shutter flapped back and forth groaning and creaking most dismally. We used to sit around the stove to study or recite, one division making way for another as we alternately scorched or froze. It was the pursuit of knowledge under difficulties but we made the time count for all that.

In this school six families were represented by twentythree pupils. With the exception of Biernatzki brothers, William, Henry, and Albert, and my own brothers, Charles, Ulysses and Frank, ${ }^{7}$ I have lost trace of them. Albert Biernatzki, as bonnie a brown-eyed laddie as ever blessed a mother's heart and home, was first inured to alphabetic toils, while his brothers had already attained to the dignity of the third reader and a primary arithmetic. William is now in business in Webster City; Henry died in 1893 and Albert is now Judge Biernatzki of Salem, South Dakota.

\section{CONTENDS WiTH RIgors of WINTER}

The next spring (1868) I returned to the Hunt school. New settlers had increased the number of pupils to seventeen. The road was less rough and wild than the

The Woodleaf school-house now stands on the Kamrar road, a few rods east from Highway No. 60, but it used to stand on the southeast corner next to the highway.

TUlysses Briggs, called "Ulis" by the family, is now living at the age of elghty-six, in Ukiah, California. Charles Briggs, a stone mason and contractor, died at the Briggs farm home in 1931. Frank Briggs, now in his eighty-fourth year, still lives on the hame place in Briggs Woods, where he owns 125 acres of land in Boone and Independence townships. 
year before, and ere the summer had passed, four of the seven creeks had well nigh disappeared.

November 9th found me again at my post ready to commence the winter term. The first week I got along pretty well, but by Tuesday of the second week, the first blizzard of the season was on-snow, frost and wind, each contending for the mastery. I started for school half an hour before daylight. Brother Ulysses with a lantern went along to help me over the nearest creek, which we crossed on stepping-stones. But my feet slipped on an icy boulder and I fell through the ice, filling my shoes with water. There was no time to go back so I struggled on through the storm over that long, weary five miles. When I reached the schoolhouse I found no one there. Even those living nearest had been unable to face the storm. I went on to Mr. Hunt's, where as ever I found welcome and good cheer. My courage had all oozed out of my frozen finger tips and for the remainder of the winter, I stayed with this kindly family.

When school closed on January 9th (1869), the snow lay heavy and deep through all the surrounding country. On the last day my brother Stephen and one of the neighbor boys came to visit the school. My brother strongly opposed my going home that night so we concluded to wait until the next morning, leaving there about nine o'clock. What a getting home it was! Hannibal crossing the Alps was a mere circumstance in comparison. At least three miles of the way lay through trackless snow that might be anywhere from two to six feet deep. An incipient January thaw had honeycombed the mass just sufficiently to let us sink through at every step. I am not quite positive as to what experiences befell my two companions in tribulation, for we were seldom within hailing distance of each other. Where the snow was not more than two feet in depth I tried to walk; when deeper I could make more progress by creeping on my hands and knees. When neither way would do, I drew my garments close about me, holding them 
fast with my hands and feet, then rolled over the ground like "Slow-solid and Stickly-prickly" after their metamorphosis. When we reached home, a little after two, we were as wet as they after they had "soaked all night in the turbid Amazon."

That summer (1869) I took charge of the Pleasant Hill' school,8 about four miles south of my home. We had some sunshine that summer, but every day we had rain sometime during the twenty-four hours. Happily my previously formed acquatic habits had made me proof against such trifles and I bore my frequent duckings and drenchings with commendable philosophy.

One lovely evening in June-we had had our morning shower-a party of young people insisted on my joining them for a walk over to the Sternberg Mills. Our road lay through deep woods, and the rank foliage produced by the abundant rains was massed everywhere in almost tropical profusion. Bright flowers gave a touch of color and from green depths came a trill of some belated bird, and over all the glory of the waning day. The old mills were nestled down among the hills in one of the most picturesque localities along the Boone. Some of the workmen were still there and piloted by them, we explored every nook and corner of the place. ${ }^{9}$

The miller, John Ross, whom the early settlers of Hamilton county remember well, was especially courteous and painstaking. Our researches ended, we stopped to rest on a great nearby $\log$ which made a convenient

8The Pleasant Hill school-house, in use today, is still located four miles south of Briggs Woods on the southeast corner of the cross road that intersects highway No. 60.

'The site of the Sternberg Mill, also known as the Ross Mill, is on the Bert Pierce farm six miles south of Webster City, in the valley of the Boone river west of the farm home. One of the mill stones from this mill may be een in the dooryard of the Pierce home. The old mill site is one of the most picturesque in the Boone valley. In the early 1900 's summer cabins were erected in this vicinity by Dr. F. J. Drake and Robert Jones "of Webster City and used for several years for summer outings.

The mystery of John Ross's murder was never solved. His nephew, John Ross, was accused of the crime, arrested and tried, but acquitted in October of 1869.

"My old path" was the one Agnes Briggs walked from the Hunt school to her home in Briggs Woods, during the terms of school which she taught in the Hunt district. 
seat. The river, dark, deep and silent as the tide of eternity, lay at our feet, and above lay,

The last high upward slant of sun upon the trees

Like a dead soldier's sword upon his pall.

We chatted a while of old times and when I rose to go, Mr. Ross said, "You must be sure to come to see us some day. At least you might come when you can't find any other place to go." "I shall come," I answered, "whether I can find another place to go or not." Little more than a week later as I was on my way to school, I met a messenger with the tidings, "John Ross was murdered last night." How strange and awful it seemed! I kept my promise and went to see him; but the closed eyes gave me no look of recognition, and the poor discolored face no smile of welcome. ${ }^{9}$

\section{A HOLIDAY JOURNEY}

The winter of $1870-71$, I received a very pressing invition to preside over the Randall school, ${ }^{10}$ at the then extravagant salary of thirty-five dollars per month. Such a temptation was not to be resisted, though the school was more than twenty miles from home. Here I had fifty pupils of all ages from four to forty-five; several men recently from the old country having come to learn English. During this term I boarded with Mrs. Rasmus. Sheldahl, a daughter of Lars Henryson, who was for many years a member of the Hamilton county board of supervisors. Modern luxuries were not much in evidence here, but the people were very kind and did their best. for me and that was good enough.

I had been teaching seven weeks when the director informed me that the school would expect at least a three

${ }^{10}$ The so-called Randall school in Scott, township was and is known as the Sheldahl school. It was built in 1860 and located about one and one-half miles east and one and one-half miles south of the present site of Randall. The locality was Iater known as Cristy Town. The home of Lars Henryson, father of Mrs. Rasmus Sheldahl and Judge $O$. J. Henderson, now of Webster City, was near the schoolhouse and for a number of years housed the post office of Randall.

The Sheldahl school-house was later moved to the present site of Randall but in the 1930's was restored to its original site by former pupils. It is now used as a museum for local historical collections and is called the Sheldahl Memorial Hall. Among these collections are photographs of former teachers of the school, early pioneer families, and local musical organizations. 
days' vacation for the Christmas holidays, to which they were looking forward with eager anticipation. I could not refuse, though as a rule, I object to holidays. This one happily would give me the wished for opportunity of spending Christmas under the home roof-tree. Though how to get there-it would be easy enough now-but that was long before the shriek of the whistle echoed across the fields and the rushing train roared by. The weather was severe and the snow deep; I could not ask anyone else to make such a trip. I had never before attempted so long a walk but felt certain I could manage it.

Friday evening came clear and cold. I left the school house unusually early for me but the twenty-third of December is not a long day, and the sun was already sinking into a cloud sea of gold and amethyst, when I started across the fields, thinking to reach Lakin's Grove, ${ }^{11}$ spend the night with Mrs. John Cooper and then go on in the morning.

It was a difficult matter to make much speed through that trackless waste of snow. The scene grew graver. The somber night shadows settled over all and before I had gone a mile I knew I was lost. Hungry and tired I realized I must give up my plan of reaching Mrs. Cooper's that night and content myself with trying to find the nearest place of shelter. I plodded along watching eagerly -as the lost traveller always does-for a light in some window. At last I saw a faint glimmer through the trees and with nervous haste pressed on towards it. I found that it proceeded from the tiny window of a tiny cottage in the woods. I rapped at the door; nobody came and I rapped again; still no response. I drew off my glove in order to emphasize the raps with unpadded knuckles. Inside an Indian "ghost dance" or something equally exciting and vociferous seemed to be

1"Lakins Grove is now a beautiful little stretch of woods with deep ravines along the Skunk river about one mile north of the present town of Ellsworth and seven miles from Randall. It was once a settlement with a post office station on the stage route from Marshalltown. The old Lakin home is on a hill just east of the grove, west and south of the Ellsworth cemetery. 
in progress, but I hoped that in course of time some one would hear the outside disturbance. I peeped through the little window to see what my chances were. The house had one small, unfinished room and the only visible furniture was a small, rough table on which stood the light that had attracted me-a bit of rag in a dish of grease. The place swarmed with children, eight or ten, as nearly as I could count, for they were all engaged in the wildest, maddest revel that untamed child nature is capable of. By and by a man came with a pail of milk in his hand. To him I stated my case and asked to be directed to Ambion Anderson's. With much difficulty I gathered an idea of the direction I must take and reached the place without further mishap. Their kindness, as always, was unfailing and I was warmed and fed to my heart's content.

\section{Combatting Cold and Snow}

Morning dawned clear, cold and still and by sunrise I was again on my way. A keen northwest wind was blowing and it was nearly noon when famished and chilled I reached Lakin's Grove with seven miles of my journey accomplished. I felt very reluctant about stopping, though I was acquainted with several families here. However, I feared my feet were freezing cold, so by the time I had reached the last house in the grove I dared not go by without stopping to thaw out. I was not unacquainted with the lady of the house, having often met her at church, where she had as often urged me to call. I was certain it would be no intrusion to do so now. In response to my timid rap she came to the door. I explained how I happened to be there and asked permission to come in and get warm. It was grudgingly given and on entering I drew up a chair to the stove and tried to warm my poor chilled feet. She had just taken a large pan of bread out of the oven; a big kettle of "that delicious American beverage known as porkinbeans" simmered on the back of the stove; and a pan of dried apples was bubbling on the front. True, these things were not 
dainties, but how good that food smelled. Like Esau, I was faint, and would have sold my birthright for a mess of pottage, but none was offered. I suppose the woman resented my interfering with her dinner hour. So in a few moments I took my departure relieved to find myself outside her door again. The bitter northwest wind was warm compared with her charity.

Eight miles of snow-covered prairie lay between me and the next house, which was Mr. Darrin's, but I pressed forward with that pitiless blast cutting my face and beating me back at every step. What a weary way it was! My feet moved like lead, but I reached the place at last. Miss Ella, the dark-eyed daughter of the house, met me at the door and seizing my arm, she whisked me in without ceremony and in an instant she and her mother had my wrappings off. I was placed in an arm chair by the stove and kind-hearted, motherly Mrs. Darrin tried to fit my feet into the oven by the side of a brown turkey that lay there comfortably sizzling. In vain I protested that I could stay only long enough to thaw out for it was late and I was far from home. Mr. Darrin gave me most positive assurance that I could not cross his threshold again until I had had my dinner. I shall not try to tell how good that dinner was. People who were never hungry could not be made to understand. I do not recall meeting Mr. Darrin's people again, as they removed to another county shortly after that. But, in grateful remembrance, I number them with the guests which I have with me always. ${ }^{12}$

Another hour of precious daylight had faded and it was four o'clock when I again set forth on my pilgrimage. In the meantime the weather had changed. The sky was overcast and a storm seemed imminent. The snow was falling thick and fast before I reached the place where I must turn out of the highway into the old path that I had so often traversed during my first two years of

12The Darrin or Derrin family lived a short time about eight miles from Lakins Grove on a farm near the present site of Kamrar. They removed to another county shortly after Ella, the daughter, had suffered a critical illness following an unsuccessful attempt on her life by a disappointed lover. 
work but the track was quite obliterated. Darkness came on apace, no landmarks were visible. Still undismayed I plodded on, thinking I could not lose my way on such familiar ground. I even remembered singing in the storm:

Haste, traveler, haste! the night comes on, And many a shining hour is gone;

The storm is gathering in the west

And thou art far from home and rest;

Haste, traveler, haste.

Another hour of weary wandering, when just as I had decided that I was rapidly reaching nowhere, I once more caught the glimmer of one of those ever-welcome lights in the window. I was sure it was Mr. Bauer's. I knew the place well and once reaching it, I could easily make my way home from there. On nearing the house I was surprised to find that it had an entirely unfamiliar look, and a closer survey satisfied me that I had never seen it before. I dreaded losing more time but felt compelled to stop and enquire "where I was at." I was most happily surprised when the face of an old friend appeared in the doorway-one whom I had often met though I had never visited her. It was the home of $\mathrm{Mr}$. and Mrs. Samuel McComb, two of our courageous, enterprising pioneers. ${ }^{13}$

All the while I had thought myself going north, good angels were guiding me south. Mrs. McComb would not wait for a word of explanation until she had drawn me into the house and removed my snow covered wrappings. In spite of my remonstrances she insisted on preparing me a lunch. What a delicious little tea it was. Pioneer she might be but no table could be more dainty than hers. Mrs. McComb was a thoroughly womanly woman and a genuine homemaker. Given a drygoods box, a bit of cheesecloth and a paper of tacks and she would furnish

\footnotetext{
13The home of Fred Bauer stood on the site in Section 21, Independence township, just southeast of the present overhead bridge over the Northwestern railroad about two miles southeast of Briggs Woods on the road to Kamrar. In the storm, Agnes Briggs had lost her sense of direction, and instead of heading north, had gone south to the McComb home. Samuel McComb came to this home in 1867 but later removed to a farm north of the present site of Kamrar.
} 
you a home so cozy and comfortable that you would have no desire to exchange it for any other in the world. Lunch disposed of, like poor little Joe, I realized that I "must be movin' on," and prepared to do so, though they firmly insisted on my remaining with them that night. But I was reluctant to trespass further on their hospitality, especially when I was so near home. So I would not consent to stay.

At this crisis an idea dawned on Mr. McComb and he pleaded on his own behalf-"Wouldn't I stay and read a novel to him? I was such a beautiful reader and he so loved to hear me." Of course if I felt that I could favor them I would stay. But I have long suspected that the reading was a cunningly devised plot to keep me in out of the darkness and the storm.

It was well for me that I stayed for even in the bright light of the next day it took me nearly three hours to reach home, which was little more than two miles distant. The face of the country was so changed I could not recognize it. The broad tract of land that three years before had been open prairie was now enclosed in cultivated farms. Everything was strange and I well knew that had they permitted me to venture forth that night, I must either have wandered through the fields until morning or perished in the storm. Life's fitful fever is over for these two friends of mine, but the memory of their generous, thoughtful kindness deepens as the years pass by. As I think of them like a whisper comes the prayer for departed souls-

Eternal rest grant unto them, $O$ God

And may light perpetual shine upon them

\section{ANOTHER SCHOOL-NEW FRIENDS}

The early spring of 1871 found me plying my vocation at Rose Grove. This place will be remembered by the pioneer settlers of Hamilton county, as one of the divisions of the old stage line between Webster City and Marshalltown. Even at this day there are not lacking those who recall the time when as travellers they stayed 
their weary feet at the hospitable doors of the old wayside inn nestled among the trees. ${ }^{14}$

Here was the family home of Judge S. L. Rose and Mary E. Rose, the star of that bright household. When I first knew them in 1865, the family consisted of $\mathrm{Mr}$. and Mrs. Rose and their daughter, Emma; Mrs. Rose's parents, Mr. and Mrs. Norris ; and Mr. and Mrs. Bicknell, brother-in-law and sister of Mrs. Norris. The only other near relatives were $\mathrm{Mr}$. and Mrs. Henry Bicknell and their daughter, Alice, of Webster City. They were frequent visitors at the Grove and were always joyously welcomed. ${ }^{15}$

In this group were included some of the finest types of old age, the most superb types of maturity, and the loveliest types of youth I have ever seen. All that gentle birth, culture, wealth, and refinement could contribute was their rightful inheritance; and all of happiness that a mutual, steadfast devotion and perfect trust could bestow seemed theirs.

Many guests came and went. Most of these were from Fort Dodge. Among them were Mr. and Mrs. Haskell and their little daughter, Hattie; Mrs. Kirkup and her two young daughters, Georgie and Rose; Miss Wells, daughter of Surgeon Wells; Mr. Bassett, brother of Mrs. Kirkup, and at that time a prominent lawyer of Fort Dodge, with a host of others, whom I have ceased to recall.

${ }^{14}$ Rose Grove is today a beautiful stretch of open woods along the Skunk river. The old inn, a station on the stage line from Marshalltown to Webster City, stood on the hill at the northeast corner of the crossroads north of the present farm home of Duncan McMartin or on the southwest corner of Section 30 .

The Rose Grove school house is still on the same site as in 1871 on the southeast corner of Section 30, one mile east of the site of the old inn, where Sections 29, 30, 31, and 32 join.

${ }^{15} J u d g e$ S. L. Rose of Rose Grove was a colorful figure of his day, a man of commanding appearance, genia] manners, and political sagacity. An able lawyer, he served as district judge, chairman of the board of supervisors and president of the first county fair. One winter he edited the Hamilton County
Freeman of Webster City.

His farming operations were extensive but expensive and not always practical. He was an enthusiast and promoter and there was a hint of his being erratic in some of his dealings. His land was finally sold at sheriff's sale and he returned to the east after the death of his wife and daughter broken in body and fortune. But he was generally liked in spite of any faults. (See Jesse Lee, Hamilton County History, Volume I, pp. 151-3.) 
The old house was a lively place in those days, but among them all there was not one to compare with her, the dear mistress of the home. She was the center of that bright throng and moved as a queen among her subjects. And she was a queen-"a queen by virtue of her brow and heart, not needing to be crowned." In form she was the embodiment of grace. Her delicate oval face was framed in shining bands of soft dark hair, and lighted by wonderful dark eyes. When she flashed forth one of her quick radiant smiles, it was as though a sudden burst of sunshine had swept the place. It was a spontaneous outburst from a heart welling over with love and joy and her beneficence, like the Heavenly Father's, fell alike upon all. Like the legendary saint, she cast no shadow as she walked for she herself was sunlight. I could never associate a thought of sorrow with her or hers. For them all the days must brim with nectar, and all the years be as "starry circles, golden set."

But, in an evil hour a baleful spirit entered this fair realm and calamities followed fast upon one another. The splendid fortune with which the Norrises had dowered their daughter was dwindling rapidly; and sadder than all the death angel shadowed the home, until, one by one, with only short intervals between, were removed every member of that devoted band so long unbroken.

The first to go was poor "Grandpa Norris." He went for his accustomed walk one summer afternoon and did not return at the usual hour. They went to seek him and found him lying on the green bank "asleep." In a little while "Uncle Bicknell" and "Aunt Lucy" crossed over into the morning land to keep him company.

All these had lived long and well; their work was done and it was their time to go. But when the next shadow fell, it was not on one who had borne the burden and heat of the day, or whose life had attained its full fruition. The call was for Emma, the youngest and fairest of the household band. Our hearts rebelled against 
the stern decree, which doomed that radiant girl, so glorious in her young, glad beauty; so loved, so idolizedto the cold embrace of death. But even that mother's mighty love could not hold her back and one bright day "she passed through glory's morning gate and walked in Paradise."

Still the lonely mother kept her appointed way. There was little change save that the sweet face had grown paler and wore an expression like that in the pictures of "Mary, the mother of Jesus, as she gives up her Son."

A year or two had passed when the word reached me that she was suffering from continued ill-health, and a little later on, like thunder-clap from a clear sky, came the message, "Mrs. Rose is dead."

The last leaf on the ancestral tree was Mrs. Norris. The dear little grandmother with her gentle ways, her sweet, old time courtesy and her grand, heroic soul "with emptied arms and treasures lost" was still waiting and watching for the coming of the morning.

Then did big-hearted, generous Mrs. Henry Barstow come to the rescue, and gathered that poor, forlorn, forsaken soul under her motherly wing, with the comforting assurance, "My home shall be thy home without money and without price, until death do us part." And she rested there content to wait the little while till she could cross the boundary line and come unto her own again. The time of waiting was indeed but a little while, and one glad day she went home to family reunion in heaven.

The old homestead of Rose Grove, consisting originally of two sections of land, has long since been parcelled out to strangers-

And round about that home, the glory

That blushed and bloomed,

Is but a dim remembered story

of the old time entombed. 
There is a pathos in doing even the simplest thing for the last time. It is not alone in bidding adieu to our beloved dead that we feel this strange pain. It comes when we look our last upon the scene we have loved, or when we stand in some old familiar path that our feet may never tread again. Whether it be the closing scene in a chosen life-work, or whether we look our last upon a tree or a flower endeared by some tender memory, we still realize the hidden bitterness of that sad refrain, "The last time."

\section{Memories of the Home Place}

To me the words are associated with a thousand thronging recollections of one special locality - the dear old woods surrounding the home place. On a wooded upland whose sides slope down to encircling streams, stands the old home from which, one by one, ten of the eleven members of our family circle have played truant forever. Of all who used to fill the old rooms with life only one sad solitary figure now remains. But the sorrowful images recalled, as thought re-enters that once familiar portal, lose themselves, as it again emerges into the brightness and verdure of the woodland, every foot of which is hallowed ground.

Whether robed in spring-time beauty or in summer glories, autumn splendor, or in winter snows, the forest scene was beautiful; but especially so in spring with its wealth of bloom and verdure. Here the earliest and fairest of the wildwood blossoms opened their starry eyes; the June berries' scented snow drifted on the hillside; thickets of wild crab-apple blooms flashed their rosy glow from shadowy depths; scores of blossoming hawthorne trees spread their blossoming boughs like a fragrant white cloud overhead, while great trees. with spreading branches like protecting arms, towered above as keeping watch and ward over all. Hundreds of sylvan creatures, whose quaint beauty and curious ways made it a perpetual delight to watch them, had their homes 
here; and for our four brothers this made a veritable treasure trove of every foot of space. ${ }^{16}$

We were a busy family with little leisure and less inclination to seek recreation in accustomed ways or by conventional methods. Still we had our times of relaxation for whenever a brother came with the imperative behest-"Girls, girls! come quick! we've made another discovery!"-no matter how opportune or inopportune the time, away we all went to see the wonderful thing that had come to pass. And we were never disappointed. There was always something well worth seeing-some new species of plant or flower; or some remarkable development of animal or vegetable life; a strange bird or a peculiar fossil from the stone quarries. Nothing new or strange ever escaped their notice.

Our eldest brother, Stephen, was gifted with a marvelous insight into Mother Nature's mysteries. I had a curious impression that in some wierd fashion, he walked and talked with her as friend with friend. He knew the favorite haunts of every species of native bird or plant. He seldom failed to find the earliest of its kind and always, those first shy blossoms were gathered in the early morning into a tiny dew-gemmed cluster for one of his sisters. Sometimes he brought us flowers of peculiar varieties. I remember one cluster that resembled lilies of the valley and another time a bouquet of immense pink and white lady-slippers. Not only were we (his sisters) initiated into the mysteries of bird and insect housekeeping but the haunts of fishes and reptiles came in for a large share of our wondering admiration. We came and went as silently as the spirit of the woods without the timid creatures having been as much as aware of our presence.

${ }^{16}$ About sixty acres of this beautiful woodland has now been converted into a public park. It was given to Hamilton county in 1917 by Thirza Briggs Aldrich (Mrs. Charles Aldrich), as a memorial to Ulis and Ellen Briggs from their children.

The county board of supervisors have erected a memorial entrance gate, built a new bridge over the creek, which runs through the woods and improved the roads. The park is open to the public every day in the year, and is enjoyed in all its native woodland beauty by nature lovers from all over the county. It is truly a fitting memorial to this pioneer family. 
Through this home woods I passed each morning and evening during the time that I was teaching twenty terms of school. Just beyond the southern limit stood the little schoolhouse (now rebuilt) whither the precious mother sent her whole nest of overgrown broodlings during the winter of $1879-80 .^{6}$ It was our last winter all together and was perhaps the happiest of our lives.

It is a startling thing when death first enters the home circle, especially one so extended as ours, whose members have all been sheltered by the same roof, until the youngest has passed twenty. When three years later our brother Stephen went away from us to dwell in the endless springtime of God's greater country, he took so much of our sunshine with him that the old place never seemed quite the same again. But so fast are we gathering homeward, that the real home is there, not here; and so the changes come and the years pass by as a tale that is told.

\section{HOPES TO BE REALIZED}

The fall emigration is now at its height, every few minutes one of the white covered wagons with its miscellaneous load of human beings and household furniture, drawn by a yoke of patient oxen, may be seen on each of the great highways leading west from the Mississippi. A great field for thought is opened by the sight of the hardy pioneers to the philosophical observer. How many painful partings, how many griefs and tears, have attended this mighty exodus; and intermingled with griefs and tears, are bright hopes and visions of the future home, and peaceful farm house, all dimly seen in the dreams of the wayworn wanderers. May all their hopes be realized, and in their new home, may they find that content which failed them in the east.-Cedar Falls (Iowa) Banner, Oct. 27, 1854. 
Copyright of Annals of Iowa is the property of State of Iowa, by \& through the State Historical Society of Iowa and its content may not be copied or emailed to multiple sites or posted to a listserv without the copyright holder's express written permission. However, users may print, download, or email articles for individual use. 